\title{
APLIKASI METODE DOUBLE EXPONENTIAL SMOOTHING HOLT DAN ARIMA UNTUK MERAMALKAN VOLUNTARY COUNSELING AND TESTING (VCT) ODHA DI PROVINSI JAWA TIMUR
}

\author{
Suci Retno Ningtiyas \\ Departemen Biostatistika dan Kependudukan \\ Fakultas Kesehatan Masyarakat, Universitas Airlangga \\ Alamat Korespondensi: Suci Retno Ningtiyas \\ Email: suci.retno.ningtiyas-2015@fkm.unair.ac.id
}

\begin{abstract}
Forecasting can be used to view events or trends in future. Counseling in VCT is the counseling activities provide by psychological support, information and knowledge on HIV/AIDS, to prevent HIV transmission, promoting responsible behavior changes. This article purposed to knew number of VCT on people living with HIV in East Java province and predicted numberpeople living with HIV which recorded via the VCT in 2018 used best method. The unit of analysis in this research was the number of people living with HIV in East Java, data processed using method of Holt Double Exponential Smoothing and ARIMA. The results of forecasting data logging by VCT in people with HIV used method Holt Double Exponential Smoothing which alpha $=0.710$ and gamma=0.039 i.e $M A P E=26.06, M A D=24.75$ and $M S D=1999.59$. The alpha parameter value (level) and gamma (trend)retrieved from the way try and error. Meanwhile, ARIMA models qualifies stationerity data, white noise and residual Kolmogorov Smirnov was ARIMA (2, 1, 1) with error MAPE=45.148, $M A D=91.75$ and $M S D=437781.8$. Based on the value of MAPE, MAD and MSD that forecasting VCT was suitable to used Double Exponential Smoothing Holt. Double Exponential Smoothing Holt with $\alpha($ alpha $)=$ 0.710 and $\gamma($ gamma $)=0.039$ can produce $M A P E=26.06, M A D=24$, dan $M S D=1999.59$ produce forecasting for the year 2018, Ft $+m=S t+b t m$ F57 value $+6=S 57+b 56$, obtained results for the month of January of the year of 2018 244.769. The number of people living with HIV was recorded through VCT fluctuating but trends to rise over time. The value of forecasting has grown trend. For other researchers, because this research is univariate case, more comprehensive should added with other variables.
\end{abstract}

Keywords: Double Exponential Smoothing Holt, ARIMA, People with HIV/AIDS

\begin{abstract}
ABSTRAK
Peramalan dapat digunakan untuk melihat kejadian atau tren yang akan datang. Konseling dalam Voluntary Counseling and Testing (VCT) adalah kegiatan konseling yang menyediakan dukungan psikologis, informasi dan pengetahuan HIV/AIDS, mencegah penularan HIV, mempromosikan perubahan perilaku yang bertanggung jawab. Penelitian ini bertujuan mengetahui keadaan VCT pada ODHA di Provinsi Jawa Timur serta meramalkan ODHA yang tercatat melalui VCT pada tahun 2018 dengan metode terbaik. Unit analisis pada penelitian ini adalah jumlah ODHA di Jawa Timur, data diolah menggunakan metode peramalan Double Exponential Smoothing Holt dan ARIMA. Hasil peramalan data ODHA pencatatan VCT dengan model terbaik Double Exponential Smoothing yaitu dengan $\alpha($ alpha $)=0,710$ dan $\gamma($ gamma $)=0,039$ yaitu MAPE $=26,06$, MAD $=$ 24,75 dan MSD = 1999,59. Nilai parameter alpha (level) dan gamma (trend) diperoleh dari cara coba dan salah (trial and erorr). Metode ARIMA model yang memenuhi syarat stationeritas data, white noise dan residual berdistribusi normal adalah ARIMA $(2,1,1)$ dengan error $\mathrm{MAPE}=45,148, \mathrm{MAD}=91,75$ dan $\mathrm{MSD}=437781,8$. Berdasarkan nilai MAPE, MAD, dan MSD bahwa peramalan VCT lebih cocok menggunakan Double Exponential Smoothing karena memiliki MAPE, MAD dan MSD yang lebih kecil. Dengan $\alpha($ alpha $)=0,710$ dan $\gamma($ gamma $)=0,039$ dapat menghasilkan MAPE $=26,06$, MAD $=24,75$ dan MSD $=1999,59$ menghasilkan peramalan untuk Tahun 2018, $\mathrm{Ft}+\mathrm{m}=\mathrm{St}+\mathrm{btm}$ dengan nilai $\mathrm{F} 57+6=\mathrm{S} 57+$ b56. didapatkan hasil untuk bulan Januari tahun 2018 sebesar 244,769. Jumlah ODHA yang tercatat melalui VCT fluktuatif namun cenderung naik dari waktu ke waktu. Nilai peramalan memiliki trend naik. Bagi peneliti lain, karena penelitian ini bersifat univariat dapat ditambahakan variabel lain untuk melihat secara komprehensif.
\end{abstract}

Kata kunci: Double Exponential Smoothing Holt, ARIMA, ODHA 


\section{PENDAHULUAN}

Perencanaan yang efektif dan efisien memerlukan alat bantu peramalan yang baik. Peramalan dapat digunakan untuk melihat kejadian atau tren yang akan datang. Adanya selang waktu yang terjadi antara kesadaran suatu peristiwa dengan peristiwa itu sendiri, membuat peramalan menjadi hal yang sangat penting dalam membuat suatu perencanaan. Peramalan dibutuhkan untuk masa yang akan datang (Makridakis, 1998).

Ramalan atau prakiraan mengenai suatu keadaan di masa mendatang menjadi sangat sulit karena faktor ketidakpastian sangat besar pengaruhnya. Salah satu metode peramalan yang paling dikembangkan saat ini adalah runtun waktu (time series). Analisis runtun waktu (time series) dan peramalan (forecasting) adalah bidang penelitian yang aktif (Zhang, 2012).

Pada dasarnya peramalan ada dua macam yakni peramalan kualitatif dan peramalan kuantitatif. Peramalan dibedakan menjadi dua jika ditinjau berdasarkan sifat ramalan yang disusun, yaitu peramalan kualitatif dan peramalan kuantitatif (Assauri, 1984).

Peramalan memiliki banyak jenis, tetapi tidak semua jenis sesuai dan cocok jika diaplikasikan pada masalah tertentu. Perlu adanya ketelitian dari praktisi untuk menentukan jenis peramalan yang sesuai dengan masalah yang dihadaapi (Makridakis , 1998).

Menurut Makridakis (1998), Metode Double Exponential Smoothing Holt dan ARIMA masing-masing menganalisis data secara univariat yang mengandung pola musiman dan trend. Keduanya juga mengasumsikan nilai dan kesalahan dimasa lalu sebagai dasar peramalan dimasa datang. Namun demikian masing-masing metode juga mempunyai kekurangan dan kelebihan. Kelebihan metode Holt adalah dapat memodelkan trend dan tingkat dari suatu deret waktu, secara perhitungan lebih efisien dibandingkan dengan metode
ARIMA (rata-rata bergerak ganda). Double Exponential Smoothing Holt memerlukan data yang lebih sedikit dibandingkan dengan ARIMA. Metode ini juga memiliki fleksibilitas terhadap tingkat dan trend yang dapat dimuluskan dengan bobot yang berbeda.

Kekurangan metode Holt adalah metode ini memerlukan optimasi dari dua parameter sehingga pencarian untuk menemukan kombinasi nilai parameter yang terbaik menjadi sedikit lebih sulit. Metode ini juga tidak menyertakan pemodelan untuk sifat musiman dari suatu deret. Kelebihan metode ARIMA adalah model yang disediakan sangat beragam dan bervariasi sehingga hampir semua jenis pola data deret waktu dapat tercakup dalam pemodelannya. Ramalan yang dihasilkan oleh metode ini dapat dikembangkan untuk periode yang sangat pendek (Aries, 2007).

Kekurangan metode ARIMA adalah proses pemodelannya cukup rumit, proses perhitungannya memerlukan ketelitian dan waktu yang cukup lama, khususnya untuk optimalisasi nilai parameternya (Buffa, 1996). Cara untuk mendapatkan model peramalan yang lebih akurat, diperlukan jumlah data deret waktu yang lebih besar. Perbandingan kedua metode dalam menganalisis data dengan tingkat kesalahan (error) yang paling kecil akan menghasilkan model terbaik dalam meramalkan suatu kasus atau peristiwa. Dalam membandingkan kedua metode digunakan jumlah ODHA di Provinsi Jawa Timur (Aries, 2007).

Berdasarkan laporan Ditjen P2P, jumlah (kumulatif) kasus infeksi HIV yang dilaporkan per Juni 2016, 10 besar kasus terbanyak terdapat di Provinsi DKI Jakarta, Jawa Timur, Papua, Jawa Barat, Jawa Tengah, Sumatera Utara, Kepulauan Riau, Sulawesi Selatan, dan Kalimantan Barat. Pada bulan Desember tahun 2015 jumlah kasus AIDS di Provinsi Jawa Timur yang dilaporkan adalah 14.498 orang dan 32.646 kasus HIV. Berdasarkan jumlah tersebut, $23,3 \%$ diantaranya meninggal dunia, yakni sekitar 3.381 
orang. Angka tersebut sesungguhnya jauh lebih kecil jika dibandingkan dengan angka yang sebenarnya terjadi (Kemenkes R.I, 2016).

Kebijakan umum program nasional pengendalian HIV dan AIDS sektor kesehatan seperti upaya pencegahan yang efektif termasuk penggunaan kondom $100 \%$ pada setiap hubungan seks berisiko, tetapi upaya ini semata-mata hanya untuk memutus rantai penularan HIV. Upaya pengendalian HIV dan AIDS merupakan upaya terpadu dari peningkatan perilaku hidup sehat, pencegahan penyakit, pengobatan dan perawatan berdasarkan data dan fakta ilmiah serta dukungan terhadap ODHA. Upaya pengendalian HIV dan AIDS diselenggarakan oleh masyarakat, pemerintah, dan LSM (Lembaga Swadaya Masyarakat) berdasarkan prinsip kemitraan. Masyarakat dan LSM menjadi pelaku utama sedangkan pemerintah berkewajiban mengarahkan, membimbing dan menciptakan suasana yang mendukung terselenggaranya upaya pengendalian HIV dan AIDS. Upaya pengendalian HIV dan AIDS diutamakan pada kelompok masyarakat berperilaku risiko tinggi tetapi harus pula memperhatikan kelompok masyarakat yang rentan, termasuk yang berkaitan dengan pekerjaannya dan kelompok marjinal terhadap penularan HIV and AIDS. Berdasarkan penelitian Anita (2016) sebagian besar orang berisiko terkena HIV/AIDS memiliki effort positif dalam memeriksakan diri di pelayanan VCT.

Kebijakan operasional pengendalian HIV dan AIDS di sektor kesehatan, meliputi: pemerintah pusat bertugas melakukan regulasi dan standarisasi secara nasional kegiatan program AIDS dan pelayanan bagi ODHA. Penyelenggaran dan pelaksanaan program dilakukan sesuai azas desentralisasi dengan kabupaten atau kota sebagai titik berat manajemen program. Pengembangan layanan bagi ODHA dilakukan melalui pengkajian menyeluruh dari berbagai aspek yang meliputi: situasi epidemi daerah, beban masalah dan kemampuan, komitmen, strategi dan perencanaan, kesinambungan, fasilitas, Sumber Daya Manusia (SDM) dan pembiayaan. Sesuai dengan kewenangannya, pengembangan layanan ditentukan oleh Dinas Kesehatan. Setiap pemeriksaan untuk mendiagnosa HIV dan AIDS harus didahului dengan penjelasan yang benar dan mendapat persetujuan yang bersangkutan (informed consent). Konseling yang memadai harus diberikan sebelum dan sesudah pemeriksaan dan hasil pemeriksaan diberitahukan kepada yang bersangkutan tetapi wajib dirahasiakan kepada pihak lain.

Pemerintah sudah melakukan upaya pencegahan antara lain seperti konseling dan testing terhadap ODHA. Konseling dan testing terhadap ODHA dibagi menjadi dua yaitu konseling dan testing secara sukarela dan konseling testing yang diinisiasi dari petugas kesehatan yang bekerjasama dengan instansi

Konseling dalam VCT adalah kegiatan konseling yang menyediakan dukungan psikologis, informasi dan pengetahuan HIV/AIDS, mencegah penularan HIV, mempromosikan perubahan perilaku yang bertanggungjawab, pengobatan Anti Retro Viral (ARV) dan memastikan pemecahan berbagai masalah terkait dengan HIV/AIDS yang bertujuan untuk perubahan perilaku ke arah perilaku lebih sehat dan lebih aman (Depkes RI, 2006).

VCT merupakan salah satu strategi kesehatan masyarakat dan sebagai pintu masuk ke seluruh layanan kesehatan HIV/AIDS berkelanjutan yang berdasarkan prinsip, Sukarela dalam melaksanakan testing HIV Pemeriksaan HIV hanya dilaksanakan atas dasar kerelaan klien tanpa paksaan dan tanpa tekanan. Keputusan untuk melakukan pemeriksaan terletak ditangan klien. Dalam penelitian ini bertujuan untuk mengetahui model yang paling cocok untuk meramalkan VCT 
pada ODHA di Provinsi Jawa Timur tahun 2012.

\section{METODE PENELITIAN}

Jenis penelitian ini yang digunakan adalah penelitian non reaktif (non reactive research) yang merupakan jenis penelitian untuk data sekunder (Kuntoro, 2011). Berdasarkan waktu penelitian, penelitian ini merupakan penelitian cross sectional. Unit analisis pada penelitian ini adalah jumlah ODHA di Jawa Timur. Unit sampel dalam penelitian ini adalah data bulanan jumlah kasus HIV dan AIDS di Provinsi Jawa Timur yang tercatat di SIHA (Sistem Informasi HIV/AIDS) Seksi Pencegahan dan Pengendalian Penyakit Dinas Kesehatan Provinsi Jawa Timur. Data penelitian diolah dengan menggunakan metode peramalan. Metode peramalan yang digunakan Double Exponential Smoothing Holt dan Autoregrresive Integrated Moving Average (ARIMA). Tiap metode menghasilkan jumlah ODHA tahun 2018 dan diolah menggunakan aplikasi komputer.

\section{HASIL PENELITIAN}

Jumlah Orang dengan HIV/AIDS di Provinsi Jawa Timur yang tercatat melalui VTC dimana jumlahnya mengalami kenaikan dan penurunan dari waktu ke waktu. Berdasarkan data yang tercatat di Bidang Penyakit Menular di Dinas Kesehatan Provinsi Jawa Timur jumlah ODHA yang sukarela memeriksakan diri dan berkonsultasi ke petugas kesehatan pada tahun 2013 sejumlah 1263 orang, tahun 2014 sejumlah 2305 orang, tahun 2015 sejumlah 2339 orang, 2016 sebanyak 2780 orang dan tahun 2017 sampai bulan September tercatat sejumlah 2275 orang, jumlah pada tahun 2017 masih dapat meningkat lagi mengingat masih adanya 3 bulan yang tersisa.

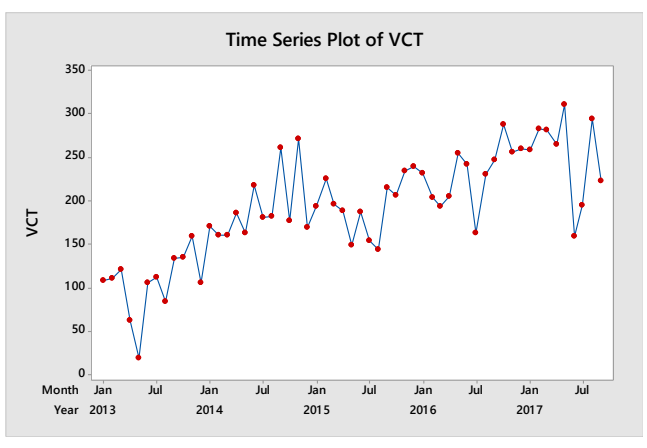

Gambar 1. Plot Data Time series

Rata-rata ODHA yang tercatat melalui VCT pada tahun 2013 sebanyak 105,2 jiwa, tahun 2014 sebanyak 192 jiwa, tahun 2015 sebanyak 194,4 jiwa, tahun 2016 sebanyak 231 jiwa, tahun 2017 sebanyak 251 jiwa dengan rata-rata terbanyak pada tahun 2017. Jumlah tersebut bisa jadi hanya sebuah fenomena gunung es yang mana dibalik dari data tersebut masih banyak kejadian yang luput dan belum tercatat di SIHA Seksi Pencegahan dan Pengendalian Penyakit Dinkes Jawa Timur (Cordeiro, 2009).

Dari data tersebut dapat dibuat plot data time series seperti yang terlihat pada Gambar 1. Menunjukkan adanya trend naik bila dilihat dari garis-garis yang menghubungkan antara satu titik dengan titik yang lain. Titik- titik tersebut didapat dengan menghubungkan data perbulan dari Januari 2013 sampai dengan September 2017.

\section{Parameter Double Exponential Smoothing Holt}

Trial dan error pada kombinasi angka 0-1 untuk mengetahui parameter $\alpha$ (alpha) dan $\gamma$ ( gamma) terbaik untuk digunakan dalam meramalkan jumlah ODHA di Provinsi Jawa Timur tahun 2018.

Berdasarkan hasil trial dan error diatas peneliti memilih model VCT terbaik dengan nilai parameter alpha (level) 0,710 dan gamma (trend) 0.039 yang memiliki (Mean Absolute Percentage Errors) MAPE sebesar 26.06, Mean Absolute Deviation (MAD) sebesar 34.75 
dan Mean Squared Deviation (MSD) sebesar 1999,59 paling minimum. Hasil parameter yang sudah terpilih dengan alpha (level) 0,710 dan gamma (trend) 0,039 dapat dilihat pada Tabel 1 .

Tabel 1. Perbandingan Parameter Trial dan Error

\begin{tabular}{|c|c|c|c|c|}
\hline \multicolumn{2}{|c|}{ Parameter } & \multirow{2}{*}{$\begin{array}{c}\text { MAP } \\
\mathbf{E}\end{array}$} & \multirow{2}{*}{ MAD } & \multirow{2}{*}{ MSD } \\
\hline $\mathbf{A}$ & $\gamma$ & & & \\
\hline 0,1 & 0,09 & 22,86 & 34,81 & 2789,3 \\
\hline 0,2 & 0,08 & 20,96 & 34,16 & 2710,3 \\
\hline 0,3 & 0,07 & 20,48 & 35,34 & 2656,4 \\
\hline 0,710 & 0,039 & 26,06 & 34,75 & 1999,5 \\
\hline 0,8 & 0,02 & 20,55 & 40,06 & 3005,0 \\
\hline 0,9 & 0,01 & 20,72 & 41,27 & 3180,5 \\
\hline
\end{tabular}

\section{Hasil Peramalan ODHA Menggunakan Double Exponential Smoothing Holt}

Diketehui bahwa dengan alpha (level) bernilai 0,710 dan gamma (trend) bernilai 0,039 maka diperoleh MAPE sebesar 26,06, MAD sebesar 34,75 dan MSD sebesar 1999,59 yang optimum sehingga langkah selanjutnya adalah penentuan pemulusan tunggal dan trend untuk data ODHA sebagaimana pertama menghitung rumus 1 (pemulusan tunggal) $\mathrm{St}=\mathrm{aXt}+(1-\mathrm{a})(\mathrm{St}-1+\mathrm{bt}-1)$ dengan dimasukkan parameter menjadi S57 = 0,710 X57 + (1-0,710) (S57-1 + b57-1). Dilanjutkan nilai koefisiennya $0.710456 \mathrm{x}$ $224+(1-0,710)((267,025)+3,1334)$ menghasilkan 237,346. Dilanjutkan dengan rumus $2 \mathrm{~B}=\mathrm{Y}(\mathrm{St}-\mathrm{St}-1)+(1-\mathrm{Y}) \mathrm{bt}-1$ dimasukkan nilai parameternya $\mathrm{B}_{57}=0,039$ (S57 - S57-1)+(1-0,039)b57-1, kemudian nilai koefisiennya $0,0391(237.365-$ $267,025)+((1-0,0391) \quad 3,1334)$ menghasilkan 1,851. Langkah terakhir dengan menambahkan antara rumus 1 dan rumus $2 \mathrm{Ft}+\mathrm{m}=\mathrm{St}+\mathrm{btm}$ dengan nilai
F57+6 = S57 + b56 dengan koefisien 237, $364+1,851$ didapatkan hasil untuk bulan Januari tahun 2018 sebesar 244,769. Dengan hasil peramalan selama 1 tahun kedepan untuk bulan Januari 2018 nilai peramalannya 244,769, Februari 2018 nilai peramalannya 246,620, Maret 2018 nilai peramalannya 248,471, April 2018 nilai peramalannya 250,322, Mei 2018 bernilai 252,173, Juni 2018 bernilai 254,024, Juli 2018 bernilai 255,875, Agustus 2018 bernilai 257,726, September 2018 bernilai 259,577, Oktober 2018 bernilai 261,428, November 2018 bernilai 263,279, dan untuk Desember 2018 nilai permalannya 265,130. Dapat disimpulkan bahwa nilai forecast selama tahun 2018 yang mengalami kenaikan di setiap bulan.

\section{Identifikasi Model ARIMA}

Dalam membuat model tahap awal analisis data adalah dengan membuat plot data. Plot data time series digunakan untuk mengetahui trend time series (Kim, 2008). Adapun hasil hasil dari plot data VCT dapat dilihat pada gambar 1 menunjukkan bahwa bentuk plot time series dari plot data VCT dengan sumbu x mewakili waktu dan sumbu y mewakili jumlah ODHA di Provinsi Jawa Timur yang tercatat melalui VCT.

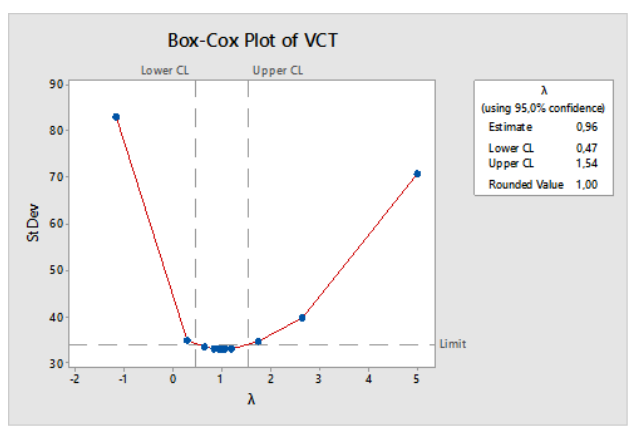

\section{Gambar 2. Box Cox Plot VCT}

Berdasarkan Gambar 2 Box Plot VCT stationer dalam varians karena lambda (rounded value) memiliki nilai 1. Nilai Lower CL 0, 47 dan Upper Cl bernilai 1,54, dengan demikian CI antara 
0,47-1,54 dan melewati angka 1 dengan derajat kesalahan sebesar 95.

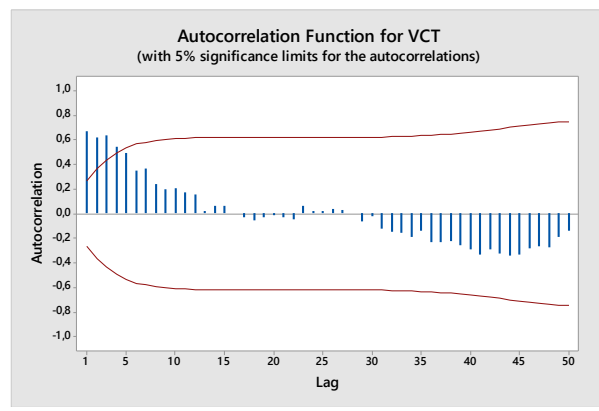

Gambar 3. Grafik ACF

Plot ACF Gambar 3 terdapat 4 lag yang melewati garis merah yang berarti menunjukkan korelasi pada garis 1, 2, 3, dan 4. Garis merah adalah selang kepercayaan yang merupakan batas signifikan autokorelasi. Berdasarkan diagram Gambar 3 dapat dikatakan bentuk ACF turun secara eksponensial akan tetapi ada 4 garis yang melewati garis merah yang berarti menandakan bahwa belum stationer dalam mean, maka selanjutnya perlu dilakukan difference.

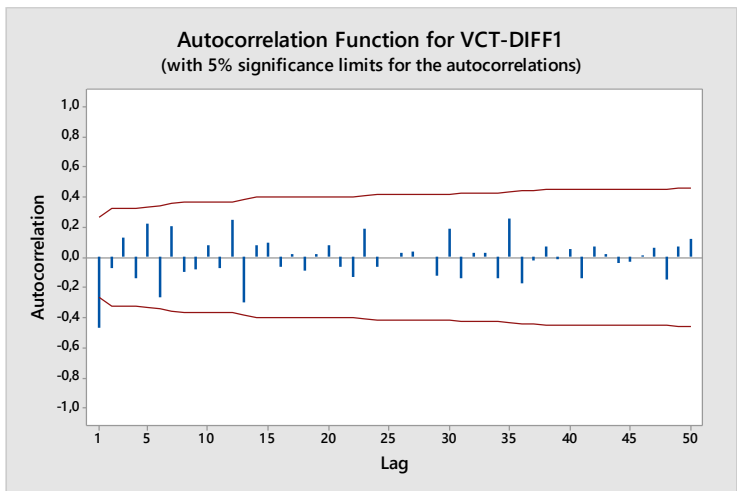

Gambar 4. Grafik ACF Setelah Difference 1

Gambar 4 merupakan hasil ACF yang sudah dilakukan difference 1 dapat dilihat bahwa pada lag 1 terdapat garis yang jatuh dan melebihi garis merah, hal ini menandakan sudah stationer dalam mean karena hanya ada 1 garis yang keluar dari garis merah.

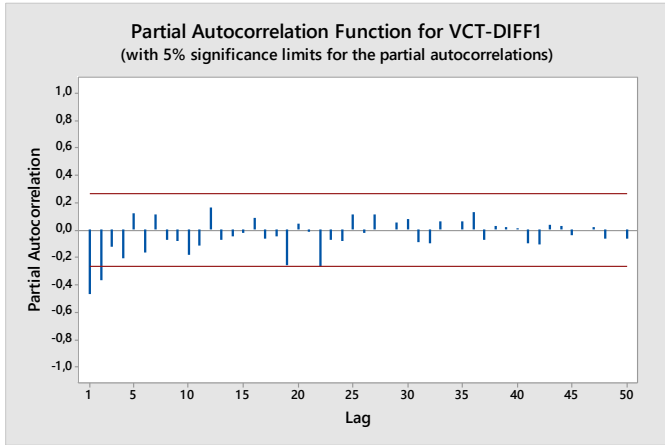

Gambar 5. Grafik PACF

Gambar 5 menunjukkan plot PACF menunjukkan ada 2 garis pada lag 1 dan lag 2 yang keluar garis merah. Dapat disimpulkan berdasarkan ACF difference 1 dan PACF data ini sudah stationer dalam mean.

Taksiran parameter model awal tersebut signifikan dengan tingkat kepercayaan 95\%. Model awal tersebut signifikan apabila nilai $p=0,00$ kurang dari $\alpha=0,05$. Berdasarkan tabel ACF dan PACF diatas untuk sementara model yang lolos uji signifikansi adalah ARIMA $(2,1,1)$, ARIMA $(2,1,0)$, ARIMA $(1,1,1)$, ARIMA $(1,1,0)$, ARIMA $(0,1,2)$, dan $\operatorname{ARIMA}(0,1,1)$

Hasil uji statistik Ljung Box yang digunakan untuk melihat white noise Ho diterima jika $p$ value lebih dari $\alpha=0,05$. Pada model yang diidentifikasi dari model yang signifikan pada $p$ value nya antara lain ARIMA $(2,1,1)$, ARIMA $(2,1,0)$, ARIMA $(1,1,1)$, ARIMA $(1,1,0)$, ARIMA $(0,1,2)$, dan ARIMA $(0,1,1)$ hanya terdapat dua model yang memenuhi syarat white noise. Pertama ARIMA $(2,1,1)$ nilai lag 12 dengan $p$ value $=0,179$, lag 24 dengan $p$ value $=0,286$, dan lag 360,291 . Nilai $p$ tersebut lebih besar dari $\alpha=0,05$, artinya bahwa residual pada ARIMA $(2,1,1)$ telah memenuhi syarat white noise (tidak ada korelasi antara residual pada lag 12, lag 24 dan lag 36). ARIMA $(0,1,2)$ nilai lag 12 dengan $p$ value $=0,136$, lag 24 dengan $p$ value $=0,184$, dan lag 360,082 . Hal tersebut memberi arti bahwa nilai $p$ lebih besar dari $\alpha=0,05$, artinya bahwa residual 
pada ARIMA $(0,1,2)$ telah memenuhi syarat white noise (tidak ada korelasi antara residual pada lag 12, lag 24 dan lag 36).

Setelah mengidentifikasi white noise dari model yang tepilih, dilanjutkan untuk melihat apakah data dari model yang terpilih memiliki distribusi normal. Nilai distribusi normal dapat dilihat dari nilai Kolmogorv Smirnov dan bentuk dari Scatter Plot. Gambar 6 menunjukkan scatter plot dari ARIMA $(2,1,1)$, Berdasarkan uji Kolmogorov Smirnov untuk ARIMA $(2,1,1)$ diperoleh nilai $p$ lebih dari 0,15 dan nilai Kolmogorov Smirnovnya sebesar 0,096 yang lebih besar dari nilai $\alpha=0,05$ sehingga ARIMA $(2,1,1)$ memiliki residual yang berdistribusi normal.

Gambar 7 untuk ARIMA $(0,1,2)$ diperoleh nilai $p$ lebih dari 0,150 dan nilai Kolmogorov Smirnov sebesar 0,097 yang lebih besar dari $\alpha=0,05$ sehingga dapat disimpulkan residual dari model ARIMA $(0,1,2)$ memenuhi asumsi berdistribusi normal.

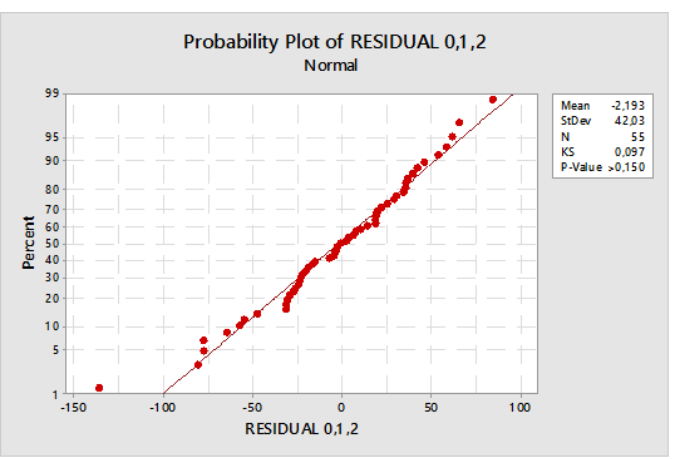

Gambar 6. Uji Kolmogorov Smirnov

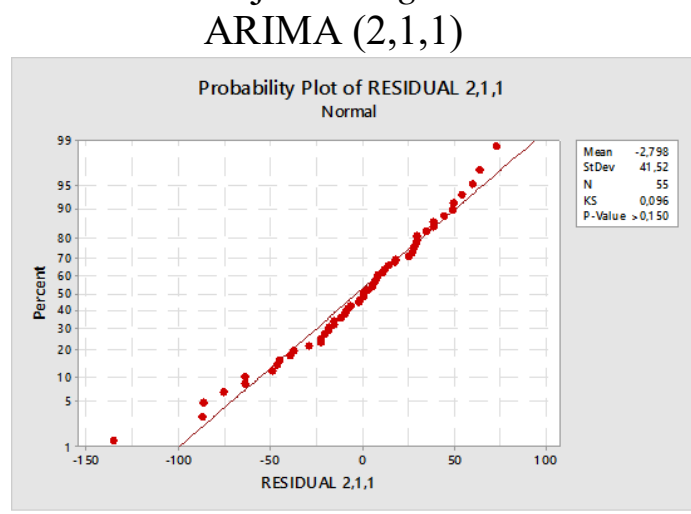

Gambar 7. Uji Kolmogorov Smirnov $\operatorname{ARIMA}(0,1,2)$

\section{Model ARIMA Terbaik}

Model ARIMA terbaik didapatkan setelah model menguji asumsi dari masingmasing model dan didapatkan hasil yang signifikan. Terdapat dua model yang signifikan yang kemudian dipilih model dengan parameter kesalahan terkecil.

Tabel 2 menunjukkan nilai error dari masing- masing model ARIMA $(2,1,1)$ dan ARIMA $(0,1,2)$ sebab dua model ARIMA tersebut memenuhi syarat permodelan ARIMA yang sesuai. Pada tabel 2 dengan melihat nilai MS dan SS nya dapat ditentukan mana model ARIMA terbaik yang digunakan, MS dan SS dipilih yang paling kecil. ARIMA $(2,1,1)$ memiliki nilai MS yang lebih kecil dari ARIMA $(0,1,2)$ yakni 1833,9 kurang dari 1840, juga untuk nilai SS nya yakni 93528,3 kurang dari 95678,7 jadi model ARIMA terbaik adalah ARIMA $(2,1,1)$ yang memiliki nilai MS dan SS yang lebih kecil.

Tabel 2. Model ARIMA Terbaik

\begin{tabular}{rcc}
\hline & \multicolumn{2}{c}{ Nilai Error } \\
\cline { 2 - 3 } Model & MSIMA & SS \\
& & \\
\hline$(2,1,1)$ & 1833,9 & 93528,3 \\
\hline$(0,1,2)$ & 1840 & 95678,7 \\
\hline
\end{tabular}

Nilai Parameter Permodelan ARIMA $(2,1,1)$

Nilai Parameter yang digunakan untuk mengetahui besarnya tingkat kesalahan.

Tabel 3. Nilai Parameter ARIMA $(2,1,1)$

\begin{tabular}{cc}
\hline \multicolumn{2}{c}{ Parameter } \\
\hline MAPE & 45,148 \\
\hline MAD & 91,75 \\
\hline MSD & 437781,8 \\
\hline
\end{tabular}


Tabel 3 dapat diketahui peramalan untuk tahun 2018 menggunakan ARIMA $(2,1,1)$ dengan error $\mathrm{MAPE}=45,148, \mathrm{MAD}=$ 91,75 dan $\mathrm{MSD}=437781,8$.

\section{Hasil Peramalan ODHA Menggunakan ARIMA}

Model ARIMA (2,1,1) dengan error $\mathrm{MAPE}=45,148, \mathrm{MAD}=91,75$ dan $\mathrm{MSD}=437781,8$. Secara matematis model ARIMA $(2,1,1)$ dapat dituliskan dalam bentuk sebagai berikut: $X_{t}=\mu^{\prime}+$ $\emptyset_{t} X_{t-i}+\emptyset_{t} X_{t-i}+e_{t}+\theta_{q} e_{t-1}$, kemudian tahapan berikutnya dilanjutkan dengan memasukan koefisien :

$$
\begin{aligned}
& X_{t}=-0,0588-0,6544 X_{t-1}-0,3915 X_{t-2} \\
& +e_{t}-0,9562 e_{t-1} \text {. } \\
& \text { Hasil peramalan selama } 1 \text { tahun }
\end{aligned}
$$
kedepan untuk bulan Januari 2018 nilai peramalannya 264,547, Februari 2018 nilai peramalannya 267,394, Maret 2018 nilai peramalannya 270,241, April 2018 nilai peramalannya 273,088, Mei 2018 bernilai 275,935, Juni 2018 bernilai 278, 782, Juli 2018 bernilai 281,629, Agustus 2018 bernilai 284,476 , September 2018 bernilai 287,323, Oktober 2018 bernilai 290,170, November 2018 bernilai 293,016, dan Desember 2018 nilai permalannya 295, 863. Nilai forecast selama tahun 2018 mengalami kenaikan di setiap bulan.

\section{Pemilihan Metode Terbaik Antara Double Exponential Smoothing Holt dan ARIMA}

Tabel 4. Nilai MAPE, MAD dan MSD Metode Double Exponential Smoothing dan ARIMA pada Data VCT

\begin{tabular}{lccc}
\hline \multicolumn{1}{c}{ Metode } & MAPE & MAD & MSD \\
\hline $\begin{array}{l}\text { Double } \\
\text { Exponential }\end{array}$ & 26,06 & 24,75 & 1999,59 \\
Smoothing & & & \\
\hline ARIMA & 45,148 & 91,75 & 437781,8 \\
$(2,1,1)$ & & & \\
\hline
\end{tabular}

Pemilihan metode terbaik antara Double Exponential Smoothing dan ARIMA dapat dilakukan dengan memilih nilai MAPE, MAD dan MSD yang minimum. Nilai MAPE pada data ODHA dengan VCT. Tabel 4 menunjukkan bahwa nilai minimum adalah pada metode Double Exponential Smoothing yaitu dengan $\alpha=$ 0,710 (alpha) dan $\gamma($ gamma $)=0,039$ yaitu MAPE $=26,06$, MAD $=24,75$ dan MSD $=$ 1999,59, sehingga dapat dikatakan metode terbaik untuk meramalkan jumlah ODHA dengan pencatatan VCT di Provinsi Jawa Timur adalah dengan metode Double Exponential Smoothing Holt (Pramita, 2010).

\section{PEMBAHASAN}

\section{Double Exponential Smoothing Holt}

Metode pemulusan eksponensial, pada dasarnya adalah data masa lalu dimuluskan dengan cara melakukan pembobotan menurun secara eksponensial terhadap nilai pengamatan yang lebih tua atau nilai yang lebih baru diberikan bobot yang relatif lebih besar dibanding nilai pengamatan yang lebih lama. Nilai $\alpha$ digunakan untuk menghaluskan perbedaan pengamatan dari periode ke periode. Metode Double Exponential Smoothing Holt digunakan untuk memodelkan data yang mengandung pola trend.

Penentuan parameter pemulusan dengan trial dan error pada metode Double Exponential Smoothing Holt dengan nilai parameter alpha dan gamma berkisar dari 0- 1. Fleksibilitas terhadap tingkat trend yang dapat dimuluskan dengan bobot yang berbeda ini menjadikan metode Holt menjadi lebih baik dalam meramalkan data dengan perubahan drastis pada waktu tertentu (Aries, 2007).

Pada metode pemulusan eksponensial, data masa lalu dimuluskan dengan cara melakukan pembobotan menurun secara eksponensial terhadap nilai pengamatan yang lebih tua atau nilai yang lebih baru diberikan bobot yang relatif lebih besar dibanding nilai 
pengamatan yang lebih lama dengan nilai alpha digunakan untuk menghaluskan perbedaan permintaan dari periode ke periode. Jadi bila selisih jumlah peminatan dari periode satu ke periode yang lain semakin besar, maka nilai alpha yang dipilih akan semakin mendekati 1 .

Pemilihan model terbaik untuk VCT menujukkan bahwa nilai MAPE, MAD atau MSD yang minimum adalah pada metode Holt Double Exponential Smoothing dengan alpha (level) $=0,710$ dan gamma $($ trend $)=0,039$ yaitu $\mathrm{MAPE}=26,06$, $\mathrm{MAD}=24,75$ dan $\mathrm{MSD}=1999,59$.

\section{Autoregressive Integrated Moving Average (ARIMA)}

Data Time series dalam penelitian ini dalah data Voluntary HIV Councelling and Testing (VCT) pada pencatatan ODHA di Provinsi Jawa Timur. Data dibagi menjadi data perbulan dari bulan Januari 2013 sampai dengan bulan September 2017 terdapat 57 data untuk masingmasing VCT. Hasil plot data time series data VCT sudah stationer dalam varians namun belum stationer dalam mean dikarenakan ada fluktuasi data yang cepat turun dan naik walaupun tidak terlalu lebar.

Pada data VCT kestationeran dalam varians dibuktikan dengan Grafik Box-Cox terdapat nilai rounded value yang telah melewati angka 1 (satu), sementara ketidak stationerannya dapat dilihat dari output ACF yang terdapat 4 garis yang melewati garis batas. Ketidak stationeran dalam means mengharuskan peneliti untuk melakukan difference. Setelah dilakukan difference sebanyak 1 kali dapat terlihat bahwa hanya ada 1garis yang melebihi garis batas dan grafik PACF menurus secara eksponensial dan hanya terdapat 2 garis yang melebihi garis merah (Octora, 2010).

ARIMA adalah metode peramalan yang sudah modern yang disusun dengan logis dan secara statistik akurat. Metode ini mampu memasukkan banyak informasi dari data historis dengan mampu menaikan akurasi peramalan dan pada waktu yang sama menjaga jumlah parameter seminimal mungkin untuk peramalan jangka panjang maupun pendek. Namun menggunakan pendekatan iteratif yang panjang dengan syarat stationer, signifikansi parameter, white noise, model dan normalitas residual sehingga menjadi rumit. Pemodelannya memang cukup rumit dimana perhitungan untuk variabel $p$ (AR), $d$ (differencing), dan $q$ (MA) diperlukan lagi perhitungan untuk menentukan besarnya parameter dari tiap variabel sehingga hasil peramalan yang dihasilkan dapat optimal. Proses perhitungan memerlukan ketelitian dan waktu yang cukup lama, khususnya untuk optimasi nilai parameternya. Agar mendapatkan model yang lebih akurat, diperlukan jumlah data yang lebih besar. Walaupun mungkin menyusun model ARIMA dengan data bulanan selama 2 tahun akan tetapi hasil yang terbaik dapat dicapai bila digunakan sekurangkurangnya data 5 sampai 10 tahun, sehingga dapat ditunjukkan dengan tepat adanya deret data dengan pengaruh musiman yang kuat (Aries, 2007).

Dalam penelitian Abdullah (2012) peneliti menggunakan 57 titik sehingga data yang digunakan kurang memenuhi untuk asumsi dari ARIMA sehingga mempengaruhi ketepatan dalam peramalan. Dapat diketahui peramalan untuk tahun 2018 menggunakan ARIMA $(2,1,1)$ dengan error $\mathrm{MAPE}=45,148$, $\mathrm{MAD}=91,75$ dan $\mathrm{MSD}=437781,8$.

\section{Metode Peramalan Terbaik}

Metode peramalan yang terbaik diperoleh dengan cara membandingkan nilai MAPE (Mean Absolute Error), MSD (Mean Square Deviation) dan MAD (Mean Absolute Devition) yang diperoleh dari masing-masing metode. Semakin kecil MAPE, MAD atau MSD, semakin kecil nilai kesalahannya. Oleh karenanya, dalam menetapkan model terbaik yang akan digunakan untuk peramalan, pilihlah model dengan nilai MAPE, MAD dan MSD yang paling kecil. 
Berdasarkan Arsyad (1995) MAD ini sangat berguna jika seorang peneliti ingin mengukur kesalahan peramalan dalam unit ukuran yang sama seperti data aslinya, sehingga pertimbangan yang digunakan apabila terjadi kesamaan nilai diantara MAPE, MAD dan MSD

Tabel 5 menunjukkan standar signifikansi nilai MAPE pada suatu peramalan. Standar signifikansi nilai MAPE menunjukkan derajat kesalahan dari suatu peramalan. Cara membaca parameter, MAPE memang lebih mudah untuk dibaca karena langsung menunjukkan persentase kesalahan. Pada VCT mempunyai MAPE sebesar 26,06, artinya kemampuan peramalan layak/ memadai (Chang et.al, 2007). Jadi peramalan VCT menggunakan Double Exponential Smoothing Holt layak digunakan untuk meramalkan VCT di tahun berikutnya.

Tabel 5. Standar Signifikansi nilai MAPE

\begin{tabular}{clc}
\hline \multicolumn{1}{c}{ MAPE } & \multicolumn{2}{c}{ Signifikansi } \\
\hline$<10 \%$ & \multicolumn{2}{l}{ Kemampuan } \\
& sangat baik & peramalan \\
\hline $10-20 \%$ & \multicolumn{2}{l}{ Kemampuan peramalan baik } \\
\hline $20-50 \%$ & $\begin{array}{l}\text { Kemampuan } \\
\text { layak/ memadai }\end{array}$ & peramalan \\
\hline$>50 \%$ & $\begin{array}{l}\text { Kemampuan } \\
\text { buruk }\end{array}$ & Peramalan \\
\hline
\end{tabular}

Pada dasarnya metode ARIMA adalah metode peramalan yang modern dan mampu menangani berbagai jenis plot data time series namun dalam penelitian ini metode Holt Linier Exponential Smoothing ternyata lebih mampu meramalkan dengan nilai MAPE, MAD atau MSD yang minimum. Hal ini terjadi karena memang data time series yang dipakai dalam analisis ini stationer dalam varians namun tidak stationer dalam mean (Noor, 2013).

Metode ARIMA mampu mengatasi segala macam jenis plot data, namun dalam penelitian ini metode Double Exponential Smoothing Holt mampu menghasilkan peramalan dengan MAPE, MAD dan MSD yang lebih kecil karena tingkat penentuan parameter yang lebih fleksibel dan syarat data yang relatif sedikit dari ARIMA meskipun untuk syarat kecukupan data dalam penelitian ini sudah memenuhi. Pola data VCT cenderung mengalami kenaikan dan tidak stabil dari waktu kewaktu, seperti plot data pada Gambar 1 terjadi penurunan secara tajam pada bulan Mei setelah itu naik secara drastis pada bulan Juni. Hal ini yang membuat rata-rata dari VCT ini tidak stationer yang mungkin mengurangi kakuratan ARIMA (Billah, 2005).

\section{Jumlah Kunjungan VCT}

Jumlah VCT yang berubah-ubah mungkin dipengaruhi faktor lain seperti kondisi fasyankes di daerah yang belum mendukung terlaksananya VCT sehingga ODHA tidak terdeteksi. Hal ini didukung penelitian Mujiati (2013), mengenai gambaran pelaksanaan VCT dan sarana prasarana klinik di Bandung, dalam penelitian tersebut menjelaskan bahwa kegiatan layanan VCT berjalan lancar namun petugasnya masih terbatas dan merangkap tugas yang lain juga keterbatasan tempat pemeriksaan yang kurang menjaga privacy dari volunter. Dalam penelitian milik Suriyani (2014), pendistribusian fasilitas layanan VCT di daerah perkotaan lebih cepat sehingga ketersediaan konselor, fasilitas layanan klinik serta suplai peralatan dan obatobatan lebih memadai.

Selain itu data VCT meningkat dari waktu kewaktu, hal ini menandakan bahwa individu mulai sadar akan manfaat VCT, seperti pada penelitian Pibriana (2013), individu yang memiliki persepsi manfaat VCT tinggi memiliki proporsi lebih besar untuk melakukan VCT dibandingkan individu yang memiliki persepsi rendah. Hal ini didukung oleh penelitian Anggraini (2014), kesadaran akan pemeriksaan VCT di pengaruhi oleh tingkat pendidikan individu, dalam penelitiannya responden yang memiliki pendidikan tinggi 100\% melakukan pemeriksaan VCT, sementara yang berpendidikan sedang $25 \%$ melakukan pemeriksaan VCT, dan yang 
memiliki pendidikan rendah $0 \%$ yang melakukan pemeriksaan VCT (Hye, 2013). Peningkatan jumlah VCT yang naik dari tahun ketahun dapat dipengaruhi tingkat pendidikan di Provinsi Jawa Timur yang tergolong baik, sehingga masyarakat sadar untuk memeriksakan dirinya.

Pemeriksaan yang diselenggarakan oleh instansi juga semakin banyak salah satunya di Rumah Tahanan (Rutan). Pada penelitian Muhith 2012, pemeriksaan VCT pada Warga Binaan Permasyarakatan (WBP) sudah dilakukan namun masih belum optimal dalam pelaksanaannya, SOP untuk menjalankan VCT sudah ada namun masih terbatas dari segi sumber daya yang dibutuhkan (Hugo, 2011).

\section{SIMPULAN}

Hasil peramalan data ODHA pencatatan VCT dengan model terbaik Double Exponential Smoothing yaitu dengan $\alpha($ alpha $)=0,710$ dan $\gamma($ gamma $)=$ 0,039 yaitu $\mathrm{MAPE}=26,06, \mathrm{MAD}=24,75$ dan MSD $=1999,59$. Nilai parameter alpha (level) dan gamma (trend) diperoleh dari cara coba dan salah (trial and erorr). Metode ARIMA yang memenuhi syarat stationeritas data, white noise dan residual berdistribusi normal adalah ARIMA $(2,1,1)$ dengan error $\mathrm{MAPE}=45,148$, $\mathrm{MAD}=91,75$ dan $\mathrm{MSD}=437781,8$. Berdasarkan nilai MAPE, MAD, dan MSD bahwa peramalan VCT lebih cocok menggunakan Double Exponential Smoothing karena memiliki MAPE, MAD dan MSD yang lebih kecil.

Hasil peramalan penjaringan ODHA dengan metode terbaik Double Exponential Smoothing Holt didapatkan hasilnya untuk VCT di Provinsi Jawa Timur sebagai berikut, dengan $\alpha($ alpha $)=$ 0,710 dan $\gamma($ gamma $)=0,039$ yaitu pada bulan Januari 2018 (244,769), Februari 2018 (246,620), Maret 2018 (248,471), April 2018 (250,322), Mei 2018 (252,173) dan Juni 2018 (254,024), Juli 2018 (255, 875), Agustus (2018 257, 726), September $2018(259,577)$, Oktober $2018(261,428)$,
November 2018 (263, 279), dan untuk Desember $2018(265,130)$.

Peramalan (forecast) yang menggunakan model Double Exponential Smoothing Holt dalam penelitian ini untuk meramalkan jumlah ODHA yang terjaring melalui VCT dan bersifat univariat yang hanya didasarkan pada data kunjungan pasien. Agar dapat melihat lebih komprehensif bisa ditambahkan variabel lain yang mungkin bisa mempengaruhi variasi series data jumlah ODHA (Durojaiye, 2011).

Peramalan model Double Exponential Smoothing Holt memberikan hasil yang peramalan dengan jumlah ODHA yang relatif meningkat sehingga diharapkan dapat membantu dalam pertimbangan perencanaan untuk memonitoring dan evaluasi program pencegahan terhadap HIV/AIDS serta perawatan pada ODHA, serta lebih ditingkatkan lagi sistem koodinasi dan sosialisasi agar menciptakan kesadaran pada diri masyarakat akan pentingnya melakukan VCT.( Anggraini, 2015)

\section{DAFTAR PUSTAKA}

Abdullah, L., 2012 ARIMA Model for Gold Bullion Coin Selling Prices Forecasting. International Journal of Advances in Applied Sciences. (IJAAS) Vol. 1, No. 4, December 2012, pp. 153 158. ISSN: 22528814.

Anggraini, Charunia. 2015. Hubungan Antara Pengetahuan Tentang HIV/AIDS Dengan Niat Melakukan VCT Pada Ibu Hamil Di Yogyakarta: Prosiding Seminar Nasional "Kesiapan Nakes Menghadapi MEA 31 Oktober 2015. Yogyakarta

Anggraini, I.G.A.2015. Faktor-Faktor Yang Mempengaruhi Pemeriksaan VCT Pada Ibu Hamil Di Puskesmas II Melaya Kabupaten Jembrana Provinsi bali: Jurnal Kebidanan STIKES Ngudi Waluyo Ungaran 
Anita., 2016. Pengaruh VCT HIV/AIDS Terhadap Perubahan Sikap Seksual Pada Kalangan Transgender Di Banda Aceh: Idea Nursing Jurnal Vol VII No 2

Aplikasi), Edisi Keenam, Jakarta: Erlangga

Aries, 2007 C/Analisis Perbandingan Pemodelan Data Deret Waktu Terbaik Antara Metode Brown's Double Exponential Smoothing, Holt's Two-Parameter Trend Model, Dan Arima Pada Total Hasil Penjualan Produk Optik Berbasiskan Komputer (studi kasus : optik ambasador).

Arsyad, Lincolin., 1995. Peramalan Bisnis. Jakarta: Gralia Indonesia

Assauri, S., (1984). Teknik dan Metode Peramalan Penerapannya dalam Ekonomi dan Dunia Usaha. Jakarta: Fakultas Ekonomi Universitas Indonesia.

Billah, B., (2005) Exponential Smoothing Model Selection for Forecasting. Maxwell L King, Ralph D Snyder and Anne $B$ Koehler. Working Paper.Department of Econometrics and Business Statistics.

Buffa, Elwood S., 1996. Manajemen Operasi dan Produksi Modern, Edisi Kedelapan, Jilid Satu, Jakarta: Binarupa Aksara.

Chang, P.-C., Wang, Y.-W., \& Liu, C.-H. (2007). The development of a weighted evolving fuzzy neural network for PCB sales forecasting. Expert Systems with Applications 32, Page 86-96

Cordeiro, C. \& Neves, M.M.(2009). Forecasting Time series With Boot. EXPOS Procedure. REVSTAT Statistical Journal ,Volume 7, Number 2, June, 135- 149. Dept.Math, FCT, University of Algarve, CEAU Land Dept.Math, ISA, TU Lisbon. Portugal.

Depkes RI. (2006). Pedoman Pelayanan Konseling Dan Testing HIV/AIDS
Secara Sukarela (Voluntary Counselling and Testing). Jakarta

Dinas Kesehatan Provinsi Jawa Timur. (2017). Seksi Pencegahan dan Pengendalian Penyakit

Durojaiye, O.2011. Knowldge, attitude and practice of HIV/AIDS: Behavior change among tertiary educations students in lagos, Nigeria.

Hugo, Graeme., 2001. Population Mobility and HIV/AIDS in Indonesia. Australia: Adelaide University. Jakarta: Binarupa Aksara.

Hye. Kyungyu., 2013. Forecasting The Number of Human Immuno Defficiency Virus Infection In the Korean Population Using Autoregressive Integrated Moving Average Model. Osong Journal of Public Health Rest Perpec. 2013 4(6) 358-362.

Kemenkes R.I, 2016. Profil Kesehatan Indonesia Tahun 2014. Jakarta: Kementerian Kesehatan RI.

Kim, J.S., Dailey, R.J., 2008. Biostatistics for Oral Healthcare. USA: Blackwell Munksgaard.

Kuntoro., 2011. Dasar Filosofis Metodologi Penelitian-Edisi 2 (Revisi) 277 Pustaka Melati, Surabaya ISBN:978-979-17866-3-8

Makridakis, S., 1998. Metode dan Aplikasi Peramalan, Jilid 1, edisi kedu, Jakarta: Erlangga.

Muhith, Abdul., VCT HIV/AIDS pada Tahanan di Rumah Tahanan Negara Kelas 1: Jurnal Ners Vol 7 No. 2 Oktober. Hal 116-120

Mujiati., 2013. Studi Kualitatif Mengenai Persepsi Dan Perilaku Seksual : Jurnal Kesehatan Reproduksi Vol.4 No 3, Desember 2013. Hal 153-160

Noor, dkk., 2013. Crime Forecasting using ARIMA Model and Fuzzy Alphacut. Journal of Applied Science 13

(1) Asian Network for Scientific Information. Malaysia: Faculty of Science and Technology.

Octora, M., (2010) Perbandingan Metode ARIMA (Box-Jenkins) dan Metode 
Winter Dalam Peramalan Jumlah Kasus Demam Berdarah Dengue. Tesis. FKM Unair Surabaya.

Pibriana, A.I. 2013. Keikutsertaan Pelanggan Wanita Pekerja Seks dalam VCT: Jurnal Kesehatan Masyarakat Vol 2 Tahun 2013. Hal 161-165

Pramita, W., (2010) Penerapan Metode Exponential Smoothing Winter Dalam Sistem Informasi Pengendalian Persediaan Produk Dan Bahan Baku Sebuah Cafe. Haryanto Tanuwijaya. Seminar Nasional Informatika (semnasIF
2010) ISSN: 1979-2328. UPN "Veteran" Yogyakarta, 22 Mei 2010

Suriyani., Nyorong, Mapeaty., natsir, Sudirman. 2014. Faktor Pendorong Pemanfaatan Layanan VCT HIV/AIDS di Kabupaten Jayapura: Jurnal Promosi Kesehatan. Universitas Hasanuddin

Zhang, Defu., A. 2012. Novel Stock Forecasting Model Based on Fuzzy Time Series and Genetic Algorithm. Department of Computer Science. Xiamen University 